\title{
Assessment of Various Empirical Soil Loss Estimation Equations in Arid Regions
}

\author{
Mahmoud M. Ahmed, Ayman G. Awadallah*, Nabil A. Awadallah, Wael T. Ahmed \\ Department of Civil Engineering, Faculty of Engineering, Fayoum University, Fayoum, Egypt \\ Email: ^aawadallah@darcairo.com
}

How to cite this paper: Ahmed, M. M., Awadallah, A. G., Awadallah, N. A., \& Ahmed, W. T. (2022). Assessment of Various Empirical Soil Loss Estimation Equations in Arid Regions. Journal of Geoscience and Environment Protection, 10, 109-122. https://doi.org/10.4236/gep.2022.101008

Received: November 29, 2021

Accepted: January 15, 2022

Published: January 18, 2022

Copyright (C) 2022 by author(s) and Scientific Research Publishing Inc. This work is licensed under the Creative Commons Attribution International License (CC BY 4.0).

http://creativecommons.org/licenses/by/4.0/

\begin{abstract}
One of the most commonly used equations to estimate soil erosion is the revised universal soil loss equation (RUSLE). Based on the early approach developed by the Soil Conservation Service of USA, the rainfall erosivity factor (R-factor) in the RUSLE equation requires sub-daily rainfall data, which is usually not available. Other empirical equations estimate R-factor based on available rainfall data like annual and monthly rainfall data. In arid regions such as the Arabian Peninsula, several studies estimated the R-factor based on these empirical equations without calibration. We propose in this paper to assess the applicability of some of these empirical equations against R-factor values calculated using as a reference the RUSLE approach. For this data, data from 104 stations with sub-daily rainfall was collected. The reference R-factor was calculated for the 104 stations. The results of seven empirical equations were tested against the reference R-factor. Most of the tested equations significantly underestimated the R-factor. Furthermore, the obtained RMSE and MAE values were almost as high as the average $\mathrm{R}$-factor, with MAPE exceeding $100 \%$. Therefore, it is recommended not to apply these equations in arid regions. A recalibration of the form of equation that gave the best results, gave an RMSE of $280(\mathrm{Mj} \cdot \mathrm{mm} /(\mathrm{ha} \cdot \mathrm{hr}))$ and the MAPE dropped to $47.6 \%$.
\end{abstract}

\section{Keywords}

Soil Erosion, RUSLE, R-Factor, Arid Region, Arabian Peninsula

\section{Introduction}

Soil in most regions of the world is playing an important role in supporting the natural ecosystems (Singer \& Warkentin, 1996). The main medium for plant growth is given by soil, which provides water, nutrients, and air. Many countries suffer from soil erosion which is considered a significant problem for some of 
them (Lal, 2001), particularly in developing countries throughout the world that rely on agriculture (Morgan et al., 1998). Soil erosion is also considered the source of the world's economic and environmental problems (Lal, 1998). A decline in soil fertility and quality, loss of topsoil, soil pollution, sedimentation and pollution of water bodies, and an overall rise in soil degradation are some of the many issues associated with soil loss and erosion (Martin-Moreno et al., 2008).

Soil erosion is defined as a physical process that detaches soil particles from the surface of the ground and removes them due to wind, rainfall, water flow, tillage or irrigation, and other forces (Segura et al., 2014; Brady \& Weil, 2010). The principal type of erosion is considered to be erosion by water. Soil erosion may not be visible on the ground surface when any amount of particles has been transported by raindrops, but soil erosion would be more evident when water forms rills and gullies flow concentrated (Kim \& Julien, 2006).

The Revised Universal Soil Loss Equation (RUSLE) (Renard et al., 1997) is the most comprehensive work for estimating the soil loss. RUSLE is an empirical model and is one of the most common methods for soil erosion estimation (Renard et al., 2011). Thanks to its simplicity and the large database, it is a very popular model (Charlton, 2007). One of the most important factors in the RUSLE equation is the rainfall erosivity R-factor which is the focus of this study. The RUSLE was enhanced by revising the climatic factor, the seasonal soil erodibility factor, updating the gradient and slope length, and inventing a new technique for calculating the cover management factor (Renard et al., 1997). The RUSLE assumes that the sediment content of the flow controls detachment and deposition (Pitt, 2007). Erosion is limited by the flow's carrying capacity but is not limited by the source (Pitt, 2007). When the sediment load has reached the carrying capacity of the flow, detachment can no longer take place (Pitt, 2007). A full historical review of the R-factor development is given in Nearing et al. (2017).

Numerous erosion methods were used to estimate the R-Factor and the resulting soil loss over the last few decades. Yin et al. (2017) and Benavidez et al. (2018) reviewed methodologies to estimate the R-Factor, some of the different worldwide studies that developed rainfall erosivity equations, the locations in which the study was conducted, as well as the other studies that used these equations. Numerous studies focused on Europe with a special concern on impact of climate change on rainfall erosivity (Panagos et al. 2015, 2016, 2017a). Moreover, several studies estimated the R-factor to determine the effect of rainfall on soil in many sites in the Arabian Peninsula, which is study area. In Saudi Arabia, Mallick et al. (2014) used the empirical equation developed by Arnoldus (1980) to estimate the soil loss in Abha mountainous watersheds in Assir Province, Saudi Arabia. Bahrawi et al. (2016) assessed the soil erosion in Wadi Yalamlam watershed to the Southeast of Jeddah city, Saudi Arabia, using the Barfield et al. (1981) equation with annual precipitation as input. Based on the equation developed by Fournier (1960) (which is the previous form of Arnoldus (1980) equ- 
ation), Azaiez et al. (2020) provided the average soil loss due to rainfall in Wadi Mirabah, located west of the city of Abha. To the northeast of the study area, in Jordan, the equation developed by Eltaif et al. (2010) was used by Farhan et al. (2013) and Farhan \& Nawaiseh (2015) to estimate soil erosion in Wadi Kufranja watershed in the northern highlands of Jordan and in Wadi Kerak watershed is in the southeast of the Dead Sea, Jordan, respectively. All used equations were originally developed to evaluate the R-factor equation outside the Arabian Peninsula and even not in the arid and hyper-arid regions.

Unfortunately, none of the studies mentioned above calibrated the equation used to calculate the R-factor in their study area. On the other hand, Panagos et al. (2017b) produced a global map of the R-factor for the entire world, where the stations located in our study region were only 15 stations in Kuwait, which represents, in terms of area, 5.27\% of the Arabian Peninsula. The distribution of the R-factor, which is shown in Panagos et al. (2017b) study through the Arabian Peninsula, is thus mainly produced by interpolation. Therefore, the soil loss equations applied in the Arabian Peninsula were not calibrated, and the current research tries to fill this scientific gap which is considered the main objective for this paper.

\section{Study Area Characteristics and Data Sources}

\subsection{Study Area}

The study area is the Arabian Peninsula, located from $12^{\circ} \mathrm{N}$ to $32^{\circ} \mathrm{N}$ and from $36^{\circ} \mathrm{E}$ to $61^{\circ} \mathrm{E}$. The Arabian Peninsula is one of the biggest deserts in the world. The area of the Arabian Peninsula is around 3.2 million $\mathrm{km}^{2}$, approximately the size of the Indian subcontinent. It is located in Southwest Asia and joins Asia with Africa. It is bordered by the Levant area (a region known as the Fertile Crescent) to the north, the Red Sea to the west and southwest, the Arabian Gulf to the northeast, and the Indian Ocean to the southeast. The length of the Red Sea boundary is approximately 1900 kilometers and the maximum width is 2500 kilometers from Yemen to Oman (Nijim et al., 2019).

\subsection{Data Sources}

The available sub-daily rainfall data obtained from the rainfall stations in the study area are obtained from 104 stations. Exactly 49 stations are available in Oman, one (1) station in Dubai and 54 stations in Saudi Arabia. The 104 stations of Oman, Dubai and Saudi Arabia provide sub-daily rainfall data. The study area and the used rainfall stations with available sub-daily rainfall data are shown in Figure 1.

\section{Methodology}

\subsection{Evaluation of the $\mathrm{EI}_{30}$ Using Sub-Daily-Duration Rainfall Data}

The RUSLE model equation is given below: 


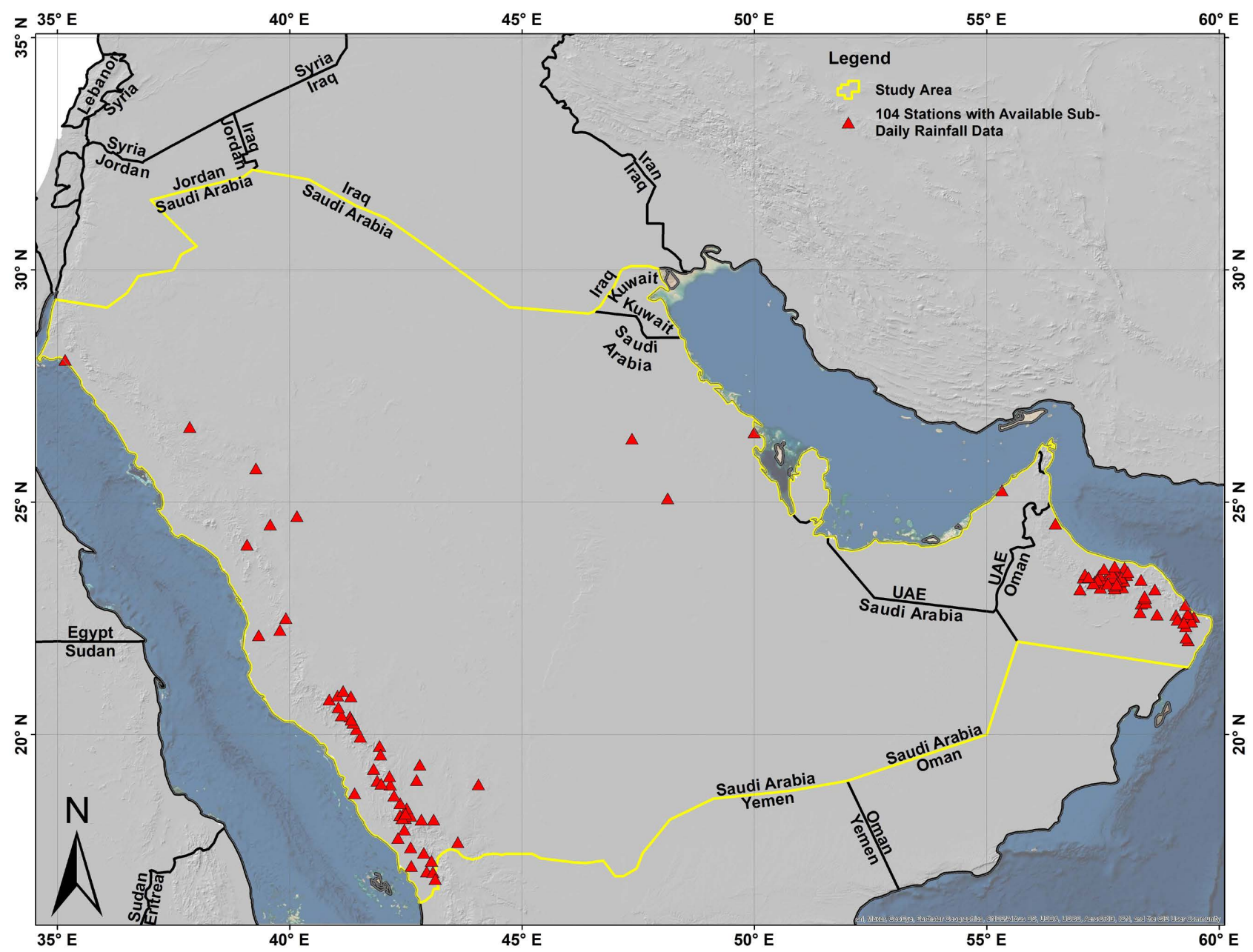

Figure 1. Study area and rainfall stations with available sub-daily data.

where:

$A-$ Annual soil loss, in tons $\cdot \mathrm{ha}^{-1} \cdot \mathrm{year}^{-1}$.

$R$-Rainfall erosivity factor in MJ.mm/(ha.hr.year).

$K$-Soil erodibility factor, the erosion rate for a specific soil in continuous fallow condition on a $9 \%$ slope having a length of $22.1 \mathrm{~m}$ in ton $\cdot h a \cdot h r /(M J \cdot m m \cdot h a)$.

$L S$-Topographic factor that reflects the length of the slope and steepness of the slope. It is the soil loss ratio of a particular site to that from a unit site with the same soil and slope but with a length of $22.1 \mathrm{~m}$.

$C$-Cover management factor, which is the protective covering of the canopy and organic material in direct contact with the soil. It is calculated as the ratio of soil loss from land cultivated under particular circumstances to the corresponding loss from tilled land under clean-tilled continuous fallow conditions (Renard et al., 1997).

$P S$-Support practice factor that reflects the activities of soil protection or other erosion control measures. It is measured as the soil loss ratio with a particular support practice to the corresponding loss with up and downslope plowing 
(Renard et al., 1997).

In general, the rainfall data have been recorded in the rainfall stations in the form of the depth of rainfall versus its duration. EI30 was evaluated according to Wischmeier \& Smith (1978) method. The R-factor is obtained by applying in Equation (2).

$$
R=\frac{1}{n} \sum_{j=1}^{n}\left[\sum_{k=1}^{m}(E)\left(I_{30}\right)_{K}\right]
$$

where:

$R$-Rainfall erosivity factor;

$E$-total storm kinetic energy (MJ/ha);

$I_{30}$-maximum 30 minutes rainfall intensity;

$j$-index for the number of years used to calculate the average;

$k$-index of the number of storms every year;

$n$-number of years to find the average;

$m$-number of storms every year.

\subsection{Investigation of the Published Equations}

Previously published equations estimating the $\mathrm{R}$ factor based on available rainfall data such as annual rainfall data $(\mathrm{P})$ were investigated to determine their applicability in the Arabian Peninsula by comparing the outcome of the various equations against the calculated R-factor using sub-daily rainfall data. Table 1 shows the forms and parameters of these equations, which vary between fractional equation, linear equation, power equation and exponential equation as shown in Table 1.

\subsection{Performance Criteria}

The performance criteria were used to find out how similar the values and model simulations observed are. To assess model performance, correlation-based methods are widely used. To compare models, these mathematical criteria are used to calculate some kind of distance between the simulated values and the reference values (Waseem et al., 2017). There are several performance criteria to evaluate models. Three of these criteria are used in this study:

Table 1. Published equations using commonly available rainfall data as input.

\begin{tabular}{cc}
\hline Equation & Reference \\
\hline$R=\frac{2.5 P^{2}}{100(0.073 P+0.73)}$ & (Bols, 1978) \\
$R=-3172+7.562 P$ & (Mikhailova et al., 1997) \\
$R=-944+3.08 P$ & (Torri et al., 2006) \\
$R=0.04830 P^{1.61}, P<850 \mathrm{~mm}$ & (Kenneth G. Renard \& Freimund, 1994) \\
$R=(0.5 \pm 0.05) * P$ & (Roose, 1976) \\
$R=9.08 * 0.0115 P^{1.4947}$ & (Jung et al., 1983) \\
$R=23.61 * \mathrm{e}^{0.0048 P}$ & (Eltaif et al., 2010)
\end{tabular}


1) the Root Mean Square Error (RMSE),

2) the Mean Absolute Percent Error (MAPE), and

3) the Mean Absolute Error (MAE).

The formulas to calculate these criteria are given hereafter in Equations (3) to (5).

$$
\begin{gathered}
\mathrm{RMSE}=\sqrt{\frac{1}{N} \sum_{i=1}^{N}\left(y_{i}-\hat{y}_{i}\right)^{2}} \\
\mathrm{MAPE}=100 * \frac{1}{N} * \sum_{i=1}^{N} \frac{\left|y_{i}-\hat{y}_{i}\right|}{\left|y_{i}\right|} \\
\mathrm{MAE}=\frac{\sum_{i=1}^{N}\left|y_{i}-\hat{y}_{i}\right|}{N}
\end{gathered}
$$

where

$y_{i}$ is the "reference" rainfall erosivity value calculated from the sub-daily information;

$\hat{y}_{i}$ is the estimated (predicted) value using any of the empirical equations;

$\bar{y}_{i}$ is the average value for the exact series; and

$N$ is the number of data points.

\section{Results and Discussions}

\subsection{Estimating Rainfall Erosivity for the Available Stations with Sub-Daily Duration Data}

Using the procedure of Wischmeier \& Smith (1978) Equation (2) calculating $\mathrm{R}$-factor per storm, adding them and then averaging for each year, the values of $\mathrm{R}$-factor were obtained. Table 2 shows the R-factor calculated for the 104 stations in the study area. R-factor ranges from $53.96(\mathrm{Mj} \cdot \mathrm{mm}) /(\mathrm{ha} \cdot \mathrm{hr})$ to 2986.43 $(\mathrm{Mj} \cdot \mathrm{mm}) /(\mathrm{ha} \cdot \mathrm{hr})$ with a mean of $680.62(\mathrm{Mj} \cdot \mathrm{mm}) /(\mathrm{ha} \cdot \mathrm{hr})$ and a standard deviation of $576.47(\mathrm{Mj} \cdot \mathrm{mm}) /(\mathrm{ha} \cdot \mathrm{hr})$.

\subsection{Assessment of the R-Factor Empirical Equations}

Various equations estimate the R-factor based on the mean annual rainfall as input. In this study, seven (7) previously published equations were assessed against the exact $\mathrm{R}$-factor estimated from sub-daily rainfall data. The scatter plots between the exact (reference) R-factor (which is the value of the R-factor obtained from sub-daily rainfall data) and the calculated R-factor by previously published equations are illustrated superimposed distributed on the $45^{\circ}$ (1:1) line (Figure 2). The 1:1 line allows identifying how the reference values compare with the estimated ones by published equations. All tested equations except Roose (1976) significantly underestimated the R-factor. In fact, equations like Mikhailova et al. (1997) and Torri et al. (2006) even produced negative R-factor values. On the contrary, Roose (1976) equation produced overestimated values. Furthermore, the obtained RMSE and MAE values were almost as high as the average R-factor, with MAPE exceeding 100\% (Table 3). Based on the above, the 
Table 2. Reference rainfall erosivity values for the 104 stations.

\begin{tabular}{|c|c|c|c|c|c|c|c|}
\hline $\begin{array}{l}\text { Station } \\
\text { Number }\end{array}$ & $\begin{array}{c}\mathrm{R} \\
(\mathrm{Mj} \cdot \mathrm{mm}) / \\
(\mathrm{ha} \cdot \mathrm{hr})\end{array}$ & $\begin{array}{l}\text { Station } \\
\text { Number }\end{array}$ & $\begin{array}{c}\mathrm{R} \\
(\mathrm{Mj} \cdot \mathrm{mm}) / \\
(\mathrm{ha} \cdot \mathrm{hr})\end{array}$ & $\begin{array}{l}\text { Station } \\
\text { Number }\end{array}$ & $\begin{array}{c}\mathrm{R} \\
(\mathrm{Mj} \cdot \mathrm{mm}) / \\
(\mathrm{ha} \cdot \mathrm{hr})\end{array}$ & $\begin{array}{l}\text { Station } \\
\text { Number }\end{array}$ & $\begin{array}{c}\mathrm{R} \\
(\mathrm{Mj} \cdot \mathrm{mm}) / \\
(\mathrm{ha} \cdot \mathrm{hr})\end{array}$ \\
\hline 1 & 609.15 & 27 & 1429.26 & 53 & 338.98 & 79 & 318.48 \\
\hline 2 & 363.92 & 28 & 758.24 & 54 & 300.56 & 80 & 2707.16 \\
\hline 3 & 502.82 & 29 & 173.35 & 55 & 1699.04 & 81 & 513.12 \\
\hline 4 & 390.46 & 30 & 397.68 & 56 & 1823.18 & 82 & 2533.41 \\
\hline 5 & 497.18 & 31 & 1295.61 & 57 & 582.42 & 83 & 538.96 \\
\hline 6 & 653.6 & 32 & 649.44 & 58 & 1053.36 & 84 & 656.57 \\
\hline 7 & 644.99 & 33 & 190.97 & 59 & 673.4 & 85 & 782.99 \\
\hline 8 & 513.71 & 34 & 274.23 & 60 & 436.69 & 86 & 1012.57 \\
\hline 9 & 314.62 & 35 & 178.99 & 61 & 754.68 & 87 & 996.83 \\
\hline 10 & 677.26 & 36 & 57.12 & 62 & 1554.8 & 88 & 1860.21 \\
\hline 11 & 874.76 & 37 & 260.77 & 63 & 259.58 & 89 & 1552.02 \\
\hline 12 & 1074.65 & 38 & 384.02 & 64 & 1409.56 & 90 & 1947.83 \\
\hline 13 & 654.09 & 39 & 207.7 & 65 & 1333.93 & 91 & 1321.85 \\
\hline 14 & 952.28 & 40 & 264.03 & 66 & 275.12 & 92 & 1412.83 \\
\hline 15 & 864.17 & 41 & 411.74 & 67 & 1090.98 & 93 & 153.85 \\
\hline 16 & 196.42 & 42 & 435.11 & 68 & 260.37 & 94 & 1099.4 \\
\hline 17 & 178.4 & 43 & 577.67 & 69 & 70.88 & 95 & 978.52 \\
\hline 18 & 211.56 & 44 & 253.94 & 70 & 188.4 & 96 & 1063.95 \\
\hline 19 & 262.65 & 45 & 680.53 & 71 & 371.15 & 97 & 2986.43 \\
\hline 20 & 422.04 & 46 & 342.44 & 72 & 432.83 & 98 & 1046.53 \\
\hline 21 & 418.18 & 47 & 316.5 & 73 & 628.35 & 99 & 432.33 \\
\hline 22 & 419.17 & 48 & 307.2 & 74 & 324.92 & 100 & 447.48 \\
\hline 23 & 212.65 & 49 & 258.49 & 75 & 53.96 & 101 & 1010.69 \\
\hline 24 & 308.88 & 50 & 175.92 & 76 & 57.32 & 102 & 328.68 \\
\hline 25 & 300.47 & 51 & 1292.05 & 77 & 104.05 & 103 & 406.99 \\
\hline 26 & 191.27 & 52 & 1207.21 & 78 & 96.53 & 104 & 1010.49 \\
\hline
\end{tabular}

Table 3. Results of assessment of published equations to evaluate the R-factor.

\begin{tabular}{cccccc}
\hline Reference & Equation Form & $\begin{array}{c}\text { Original country } \\
\text { of application }\end{array}$ & $\begin{array}{c}\text { RMSE } \\
(\mathrm{Mj} \cdot \mathrm{mm} /(\mathrm{ha} \cdot \mathrm{hr}))^{\mathrm{MAPE}}(\%)\end{array}$ \\
Bols (1978) & $R=\frac{2.5 * p^{2}}{100 *(0.073 * p+0.73)}$ & Indonesia & 842.12 & 93.05 & 640.57 \\
Roose (1976) & $R=17.02 *(0.5 \pm 0.05) * p$ & West Africa & 556.88 & 100.16 & 417.2 \\
Mikhailova et al. (1997) & $R=-3172+7.562 * p$ & Honduras & 2920 & 883 & 2900 \\
Torri et al. (2006) & $R=-944+3.08 * p$ & Italy & 1286.4 & 313.8 & 1236.8 \\
Jung et al. (1983) & $R=9.08 * 0.0115 * p^{1.4947}$ & Korea & 661.97 & 75.85 & 511.01 \\
Renard \& Freimund (1994) & $R=0.0483 * p^{1.61}$ & United States & 689.35 & 80.5 & 536.29 \\
Eltaif et al. (2010) & $R=23.61 * \mathrm{e}^{0.0048 * p}$ & Jordan & 837.6 & 89.2 & 632.1 \\
Recalibrated equation & $R=5.4228 * P$ & & 280.83 & 47.6 & 213.06 \\
\hline
\end{tabular}




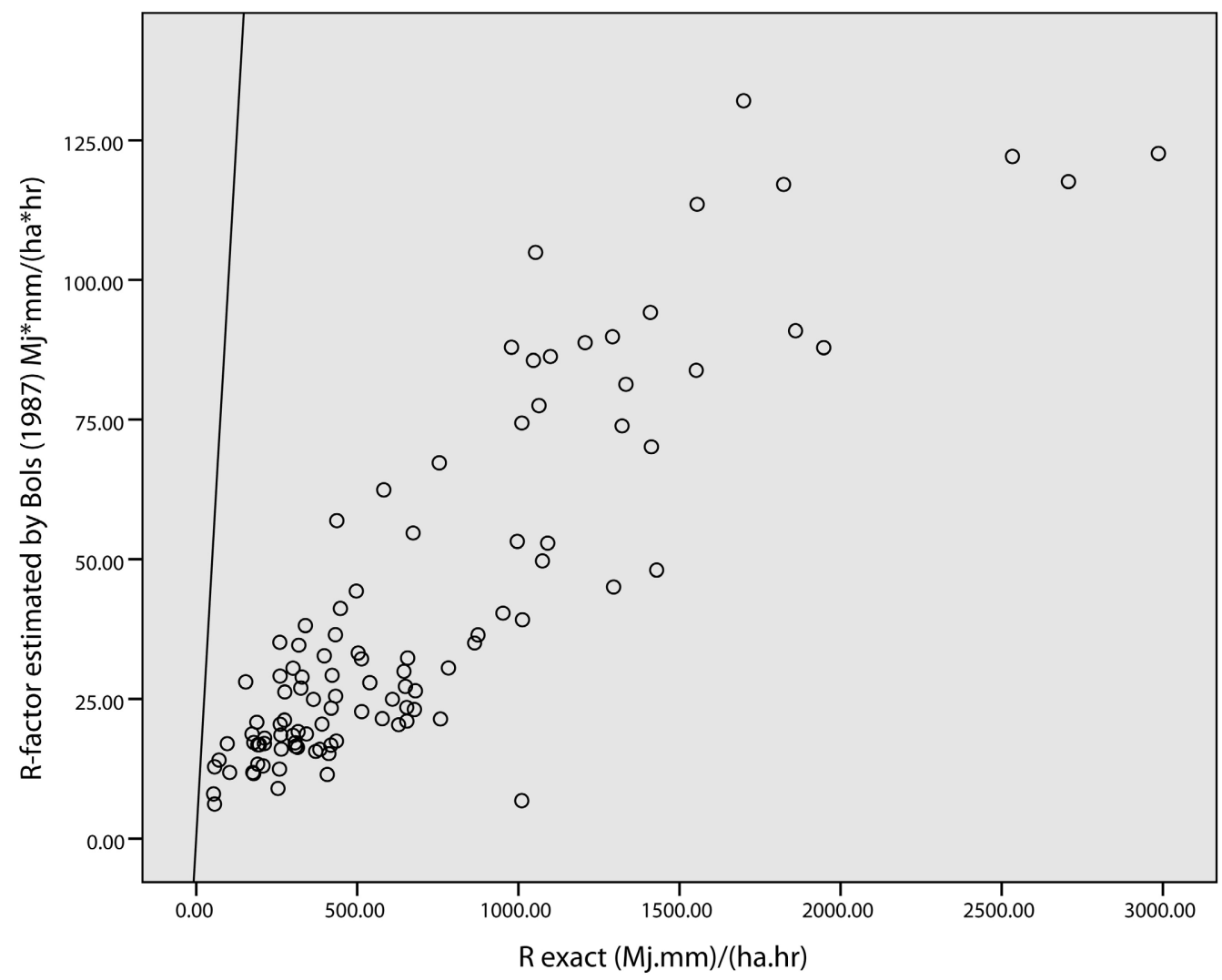

(a)

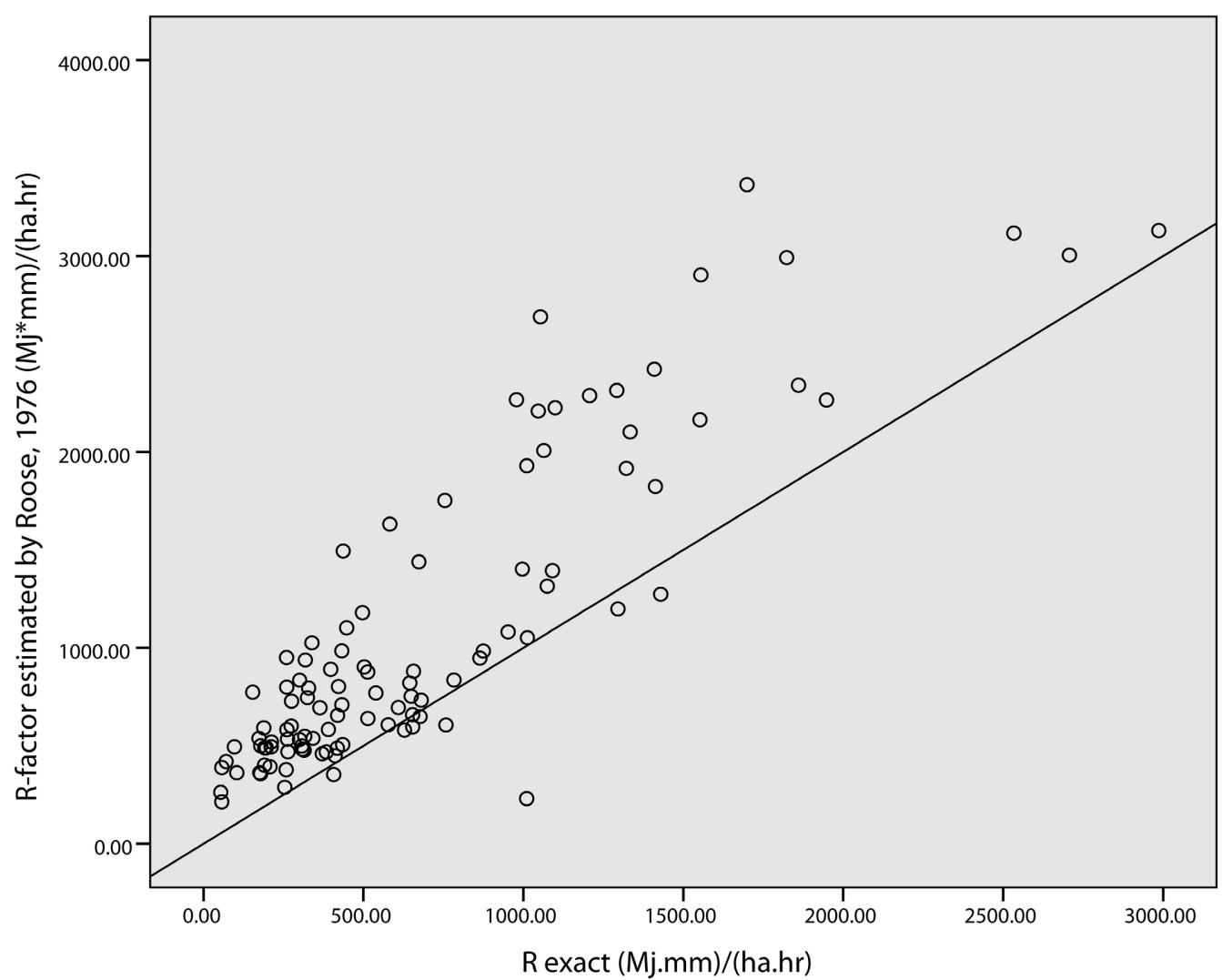

(b) 
M. M. Ahmed et al.

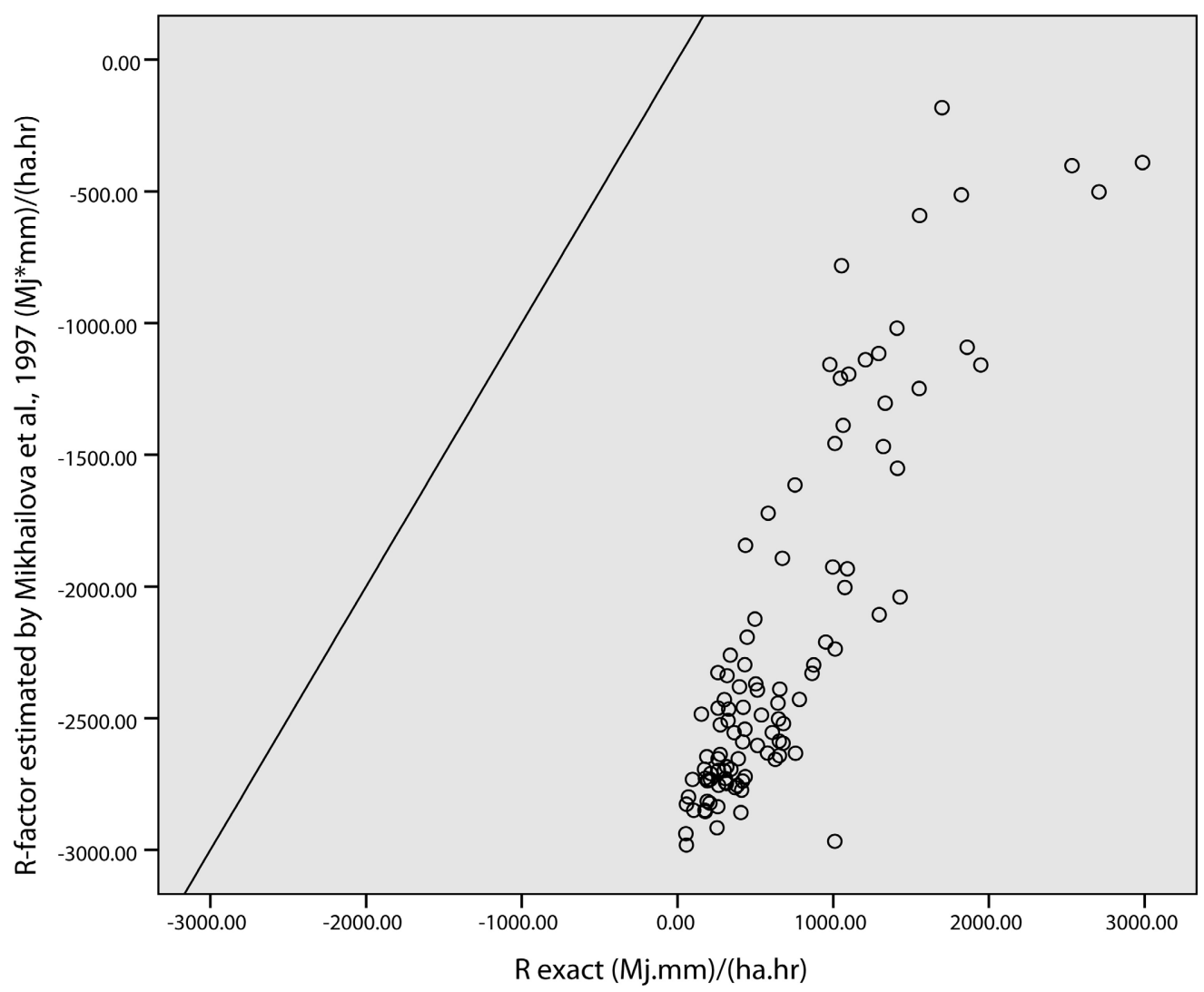

(c)

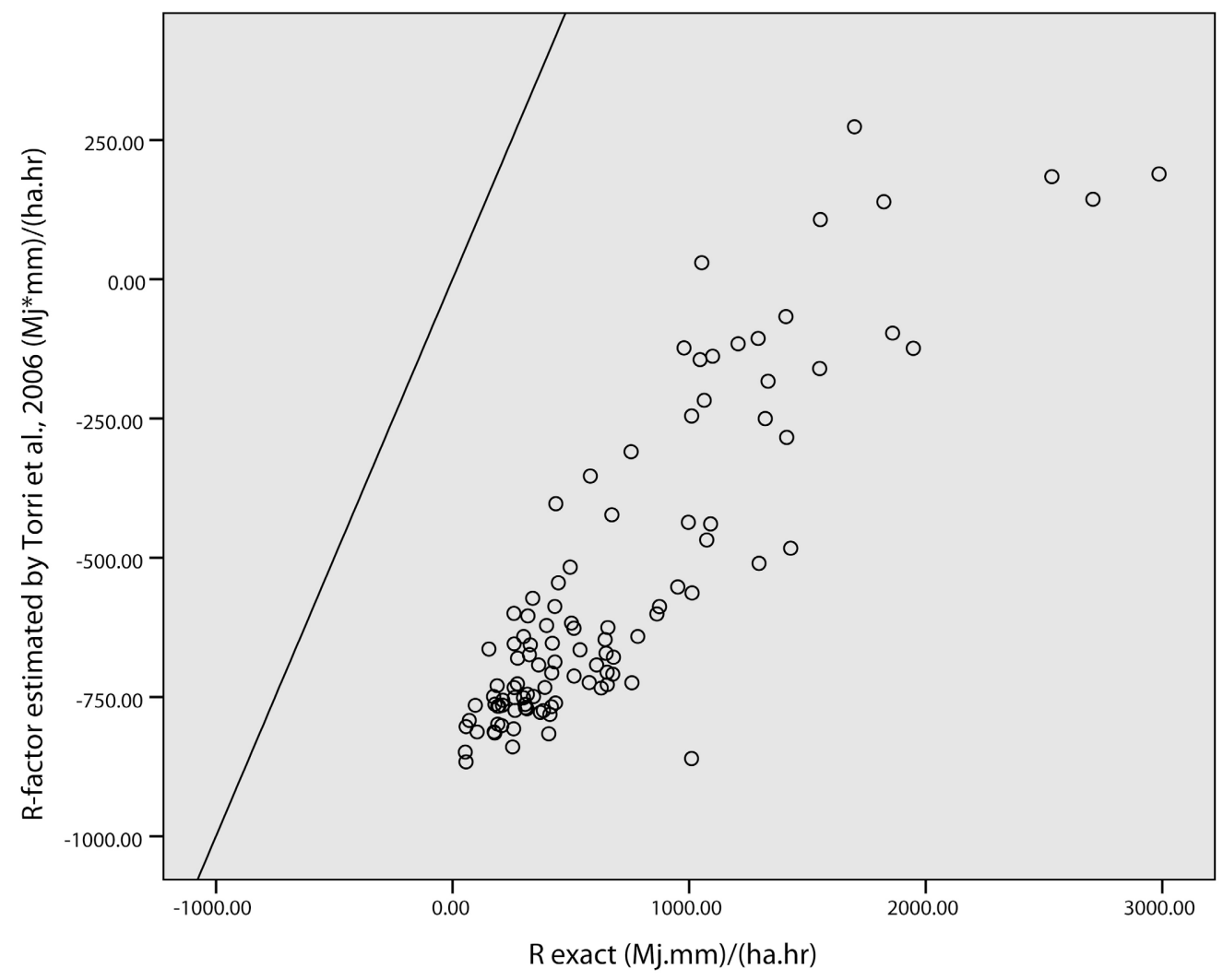

(d) 


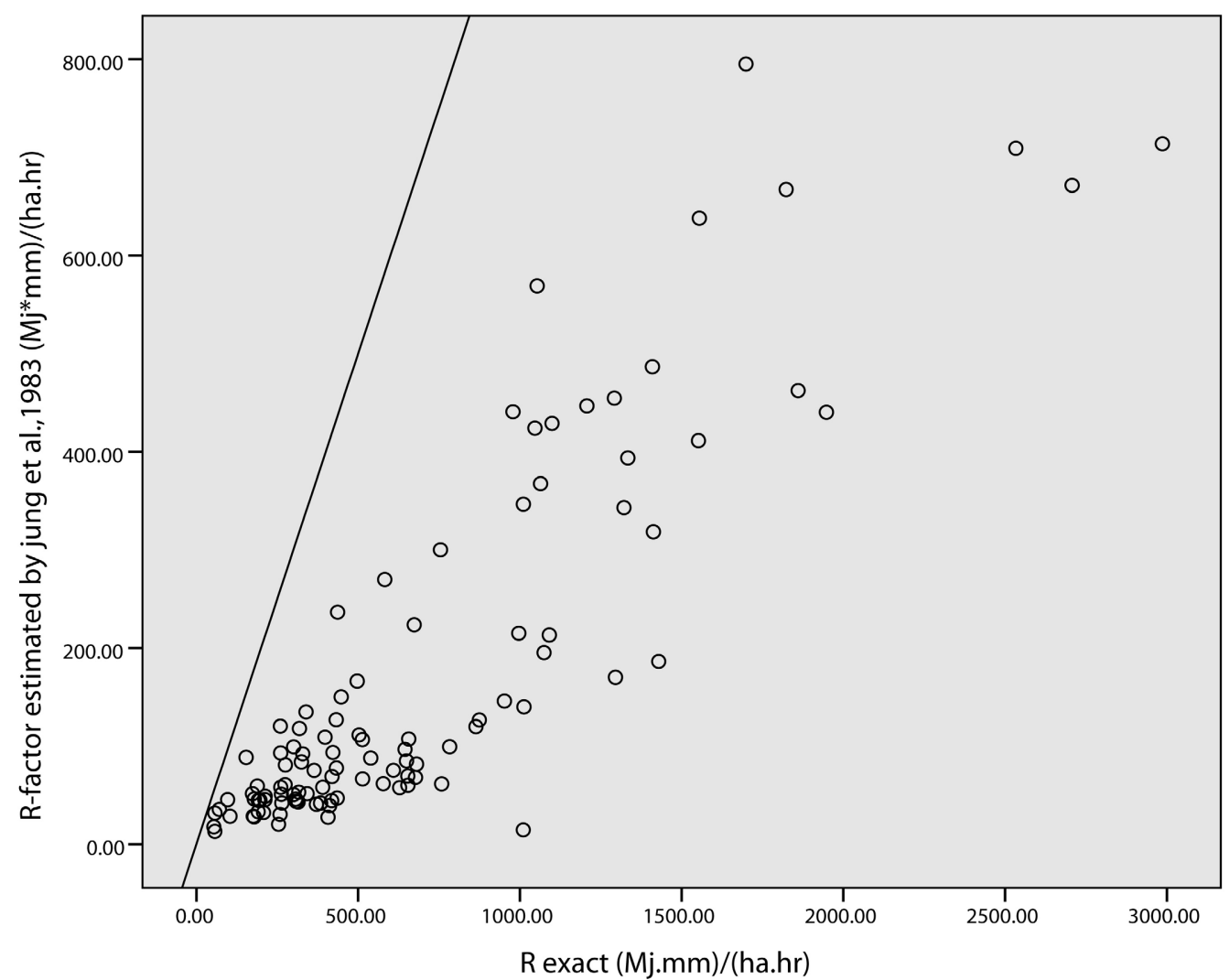

(e)

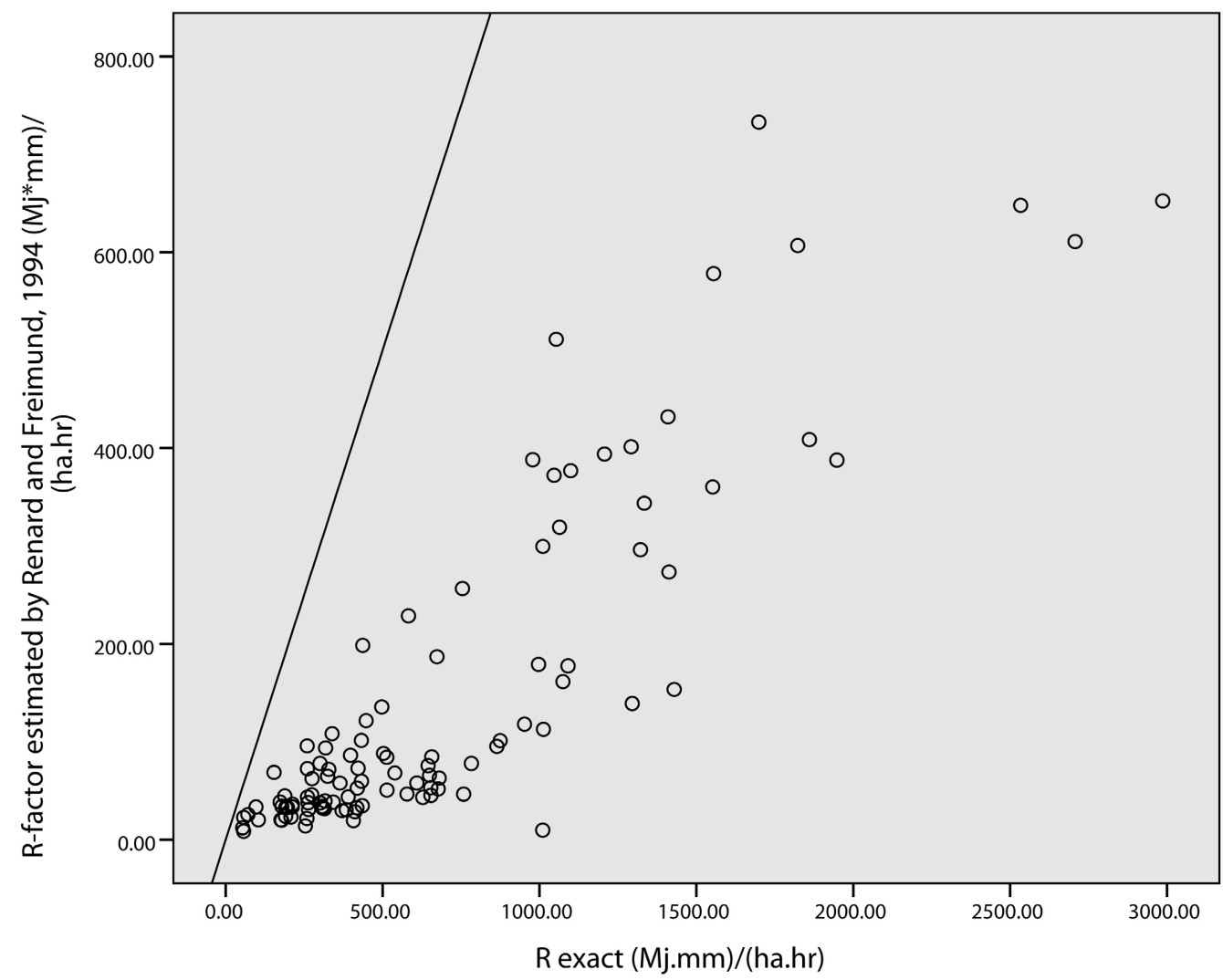

(f) 


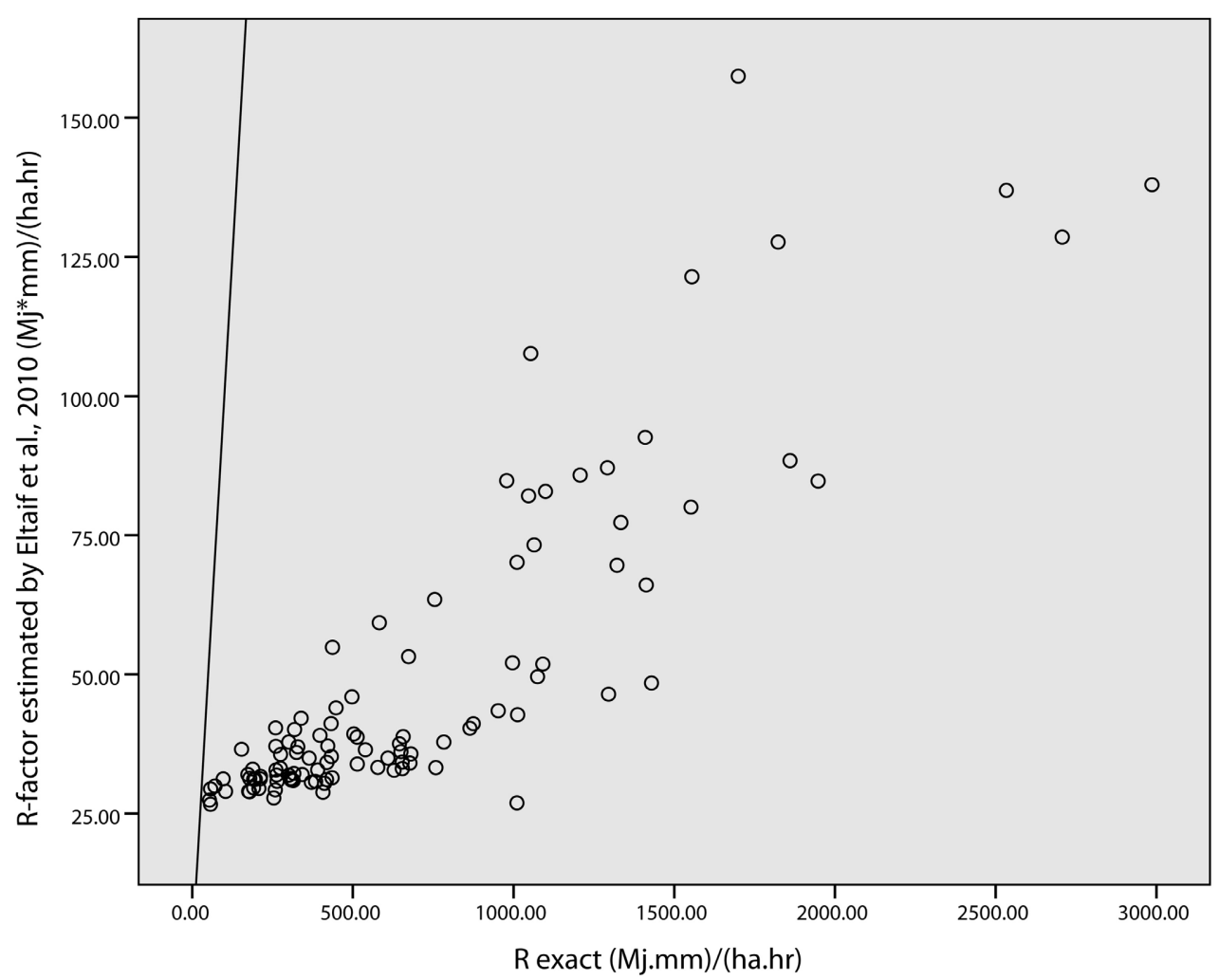

(g)

Figure 2. Reference (from Sub-Daily Rainfall Data) vs. Estimated Rainfall Erosivity Factors Using the equations of (a) Bols (1978), (b) Roose (1976), (c) Mikhailova et al. (1997), (d) Torri et al. (2006), (e) Jung et al. (1983), (f) Renard \& Freimund (1994), and (g) Eltaif et al. (2010) with superimposed 1:1 Lines.

equation that gave the best results (although unsatisfactory) was that of Roose (1976), which is a simple linear equation. We tested a recalibration of this simple form and the obtained calibrated equation (without intercept as it was not statistically significant from zero) gave an RMSE of $280(\mathrm{Mj} \cdot \mathrm{mm} /(\mathrm{ha} \cdot \mathrm{hr})$ ) and the MAPE dropped to $47.6 \%$ (Table 3).

\section{Conclusion}

Sub-daily rainfall data in 104 rainfall stations in the study area of the Arabian Peninsula are used to calculate the Erosivity R-Factor of the RUSLE equation. Using the procedure developed by the Soil Conservation Service in the late seventies, the values of the R-factor were calculated for the 104 stations and were used as reference values. The R-factor ranged from $53.96(\mathrm{Mj} \cdot \mathrm{mm}) /(\mathrm{ha} \cdot \mathrm{hr})$ to $2986.43(\mathrm{Mj} \cdot \mathrm{mm}) /(\mathrm{ha} \cdot \mathrm{hr})$ with a mean of $680.62(\mathrm{Mj} \cdot \mathrm{mm}) /(\mathrm{ha} \cdot \mathrm{hr})$ and a standard deviation of $576.47(\mathrm{Mj} \cdot \mathrm{mm}) /(\mathrm{ha} \cdot \mathrm{hr})$.

The results of seven empirical equations previously used (without calibration) in the study area were tested against the exact (reference) R-factor. All equations proved not suitable for application in the Arabian Peninsula, as an example of an arid region. All tested equations except one significantly underestimated the 
$\mathrm{R}$-factor. In fact, some of the used equations produced negative R-factor values. Furthermore, the obtained RMSE and MAE values were almost as high as the average R-factor, with MAPE exceeding 100\%. Therefore, we advise against applying these equations in the Arabian Peninsula because of their poor results. All of them require parameter recalibration. Recalibrating a simple linear regression equation gave an RMSE of $280(\mathrm{Mj} \cdot \mathrm{mm} /(\mathrm{ha} \cdot \mathrm{hr}))$ and the MAPE dropped to $47.6 \%$, when compared to the reference $\mathrm{R}$-factor values.

The current research opens a new starting point for extensive research on the different methods to predict the rainfall erosivity factor within areas with rainfall stations where only daily, monthly, or yearly precipitations are available, or regions where rainfall data is scarce. Other explanatory factors (such as elevation, wind or lee sides ...) might be investigated to see if they can improve the outcomes. We also recommend investigating the daily rainfall, or some kind of characteristics derived from it, as an explanatory factor to estimate the R-factor in arid region.

\section{Acknowledgements}

The authors would like to thank the Ministry of Regional Municipalities and Water Resources (MRMWR), Oman, and the Ministry of Environment, Water and Agriculture (MEWA), Saudi Arabia, for providing the raw rainfall data for this study.

\section{Conflicts of Interest}

The authors declare no conflicts of interest regarding the publication of this paper.

\section{References}

Arnoldus, H. M. J. (1980). An Approximation of the Rainfall Factor in the Universal Soil Loss Equation. In M. De Boodt, \& D. Gabriels (Eds). Assessment of Erosion (pp. 127-132). John Wiley and Sons.

Azaiez, N., Alleoua, A., Baazaoui, N., \& Qhtani, N. (2020). Assessment of Soil Loss in the Mirabah Basin: An Overview of the Potential of Agricultural Terraces as Ancestral Practices (Saudi Arabia). Open Journal of Soil Science, 10, 159-180.

Bahrawi, J. A., Elhag, M., Aldhebiani, A. Y., Galal, H. K., Hegazy, A. K., \& Alghailani, E. (2016). Soil Erosion Estimation Using Remote Sensing Techniques in Wadi Yalamlam Basin, Saudi Arabia. Advances in Materials Science and Engineering, 2016, Article ID: 9585962. https://doi.org/10.1155/2016/9585962

Barfield, B. J., Warner, R. C., \& Haan, C. T. (1981). Applied Hydrology and Sedimentology for Disturbed Areas (145 p). Oklahoma Technical Press.

Benavidez, R., Jackson, B., Maxwell, D., \& Norton, K. (2018). A Review of the (Revised) Universal Soil Loss Equation ((R)USLE): With a View to Increasing Its Global Applicability and Improving Soil Loss Estimates. Hydrology and Earth System Sciences, 22, 6059-6086. https://doi.org/10.5194/hess-22-6059-2018

Bols, P. (1978). The Iso-Erodent Map of Java and Madura. Belgian Technical Assistance Project ATA 105. Soil Research Institute. 
Brady, N. C., \& Weil, R. R. (2010). Elements of the Nature and Properties of Soils. Pearson Prentice Hall.

Charlton, R. (2007). Fundamentals of Fluvial Geomorphology (280 p). Routlege.

Eltaif, N. I., Gharaibeh, M. A., Al-Zaitawi, F., \& Alhamad, M. N. (2010). Approximation of Rainfall Erosivity Factors in North Jordan. Pedosphere, 20, 711-717. https://doi.org/10.1016/S1002-0160(10)60061-6

Farhan, Y., \& Nawaiseh, S. (2015). Spatial Assessment of Soil Erosion Risk Using RUSLE and GIS Techniques. Environmental Earth Sciences, 74, 4649-4669. https://doi.org/10.1007/s12665-015-4430-7

Farhan, Y., Zregat, D., \& Farhan, I. (2013). Spatial Estimation of Soil Erosion Risk Using RUSLE Approach, RS, and GIS Techniques: A Case Study of Kufranja Watershed, Northern Jordan. Journal of Water Resources and Protection, 5, 1247-1261. http://doi.org/10.4236/jwarp.2013.512134

Fournier, F. (1960). Climat et érosion: La relation entre l'érosion du sol par l'eau et les précipitations atmosphériques (201 p). Presses Universi-taires de France.

Jung, P.-K., Ko, M.-H., Im, J.-N., Um, K.-T., \& Choi, D.-U. (1983). Rainfall Erosion Factor for Estimating Soil Loss. Journal of Korean Society of Soil Science and Fertilizer, 16, 112-118.

Kim, H.-S., \& Julien, P. Y. (2006). Soil Erosion Modeling Using RUSLE and GIS on the IMHA Watershed. Water Engineering Research, 7, 29-41.

Lal, R. (1998). Soil Erosion Impact on Agronomic Productivity and Environment Quality. Critical Reviews in Plant Sciences, 17, 319-464. https://doi.org/10.1080/07352689891304249

Lal, R. (2001). Soil Degradation by Erosion. Land Degradation \& Development, 12, 519-539. https://doi.org/10.1002/ldr.472

Mallick, J., Alashker, Y., Mohammad, S. A. D., Ahmed, M., \& Hasan, M. A. (2014). Risk Assessment of Soil Erosion in Semi-Arid Mountainous Watershed in Saudi Arabia by RUSLE Model Coupled with Remote Sensing and GIS. Geocarto International, 29, 915-940. https://doi.org/10.1080/10106049.2013.868044

Martin-Moreno, C., Martin-Duque, J. F., Nicolau, J. M., Sanchez, L., Ruiz, R., Sanz, M. A., \& Zapico, I. (2008). A Geomorphic Approach for the Ecological Restoration of Kaolin Mines at the Upper Tagus Natural Park (Spain). In 6th European Conference on Ecological Restoration Ghent (pp. 1-4). Society of Ecological Restoration.

Mikhailova, E. A., Bryant, R. B., Schwager, S. J., \& Smith, S. D. (1997). Predicting Rainfall Erosivity in Honduras. Soil Science Society of America Journal, 61, 273-279. https://doi.org/10.2136/sssaj1997.03615995006100010039x

Morgan, R. P. C., Quinton, J. N., Smith, R. E., Govers, G., Poesen, J. W. A., Auerswald, K., \& Styczen, M. E. (1998). The European Soil Erosion Model (EUROSEM): A Dynamic Approach for Predicting Sediment Transport from Fields and Small Catchments. Earth Surface Processes and Landforms, 23, 527-544. https://doi.org/10.1002/(SICI)1096-9837(199806)23:6<527::AID-ESP868>3.0.CO;2-5

Nearing, M. A., Yin, S. qing, Borrelli, P., \& Polyakov, V. O. (2017). Rainfall Erosivity: An historical review. Catena, 157, 357-362. https://doi.org/10.1016/j.catena.2017.06.004

Nijim, B. K., Serjeant, R. B., Ochsenwald, W. L., \& Rentz, G. S. (2019). Arabia. Encyclopedia Britannica. https://www.britannica.com/place/Arabia-peninsula-Asia

Panagos, P., Ballabio, C., Borrelli, P., \& Meusburger, K. (2016). Spatio-Temporal Analysis of Rainfall Erosivity and Erosivity Density in Greece. Catena, 137, 161-172.

https://doi.org/10.1016/j.catena.2015.09.015 
Panagos, P., Ballabio, C., Borrelli, P., Meusburger, K., Klik, A., Rousseva, S., Alewell, C. et al. (2015). Rainfall Erosivity in Europe. Science of the Total Environnement, 511, 801-814. https://doi.org/10.1016/j.scitotenv.2015.01.008

Panagos, P., Ballabio, C., Meusburger, K., Spinoni, J., Alewell, C., \& Borrelli. P. (2017a). Towards Estimates of Future Rainfall Erosivity in Europe Based on REDES and WorldClim Datasets. Journal of Hydrology, 548, 251-262.

https://doi.org/10.1016/j.jhydrol.2017.03.006

Panagos, P., Borrelli, P., Meusburger, K., Yu, B., Klik, A., Lim, K.J. et al. (2017b). Global Rain-Fall Erosivity Assessment Based on High-Temporal Resolution Rainfall Records. Scientific Reports, 7, Article No. 4175. https://doi.org/10.1038/s41598-017-04282-8

Pitt, R. (2007). Erosion Mechanisms and the Revised Universal Soil Loss Equation (RUSLE). In R. Pitt (Ed.), Construction Site Erosion and Sediment Controls, Planning, Design and Performance. DEStech Publications, Inc.

Renard, K G, Yoder, D. C., Lightle, D. T., \& Dabney, S. M. (2011). Universal Soil Loss Equation and Revised Universal Soil Loss Equation. In R. P. C. Morgan, \& M. A. Nearing (Eds.), Handbook of Erosion Modelling (pp. 137-167). Blackwell Publishing Ltd. https://doi.org/10.1002/9781444328455.ch8

Renard, K., Foster, G., Weesies, G., McCool, D., \& Yoder, D. (1997). Predicting Soil Erosion by Water: A Guide to Conservation Planning with the Revised Universal Soil Loss Equation (RUSLE). Agricultural Handbook No. 703, United States Department of Agriculture.

Renard, Kenneth G., \& Freimund, J. R. (1994). Using Monthly Precipitation Data to Estimate the $R$-Factor in the Revised USLE. Journal of Hydrology, 157, 287-306. https://doi.org/10.1016/0022-1694(94)90110-4

Roose, E. J. (1976). Use of the Universal Soil Loss Equation to Predict Erosion in West Africa. In G. R. Foster (Ed.), Soil Erosion: Prediction and Control (pp. 60-74). Soil and Water Conservation Society of America.

Segura, C., Sun, G., McNulty, S., \& Zhang, Y. (2014). Potential Impacts of Climate Change on Soil Erosion Vulnerability across the Conterminous United States. Journal of Soil and Water Conservation, 69, 171-181. https://doi.org/10.2489/jswc.69.2.171

Singer, M. J., \& Warkentin, B. P. (1996). Soils in an Environmental Context: An American Perspective. Catena, 27, 179-189. https://doi.org/10.1016/0341-8162(96)00016-1

Torri, D., Borselli, L., Guzzetti, F., Calzolari, M. C., Bazzoffi, P., Ungaro, F., \& Sanchis, M. P. S. (2006). Soil Erosion in Italy. In J. Boardman, \& J. Poesen (Eds.), Soil Erosion in Europe (pp. 245-261). Wiley Online Library.

Waseem, M., Mani, N., Andiego, G., \& Usman, M. (2017). A Review of Criteria of Fit for Hydrological Models. International Research Journal of Engineering and Technology, 4, 1765-1772. https://www.irjet.net

Wischmeier, W. H., \& Smith, D. D. (1978). Predicting Rainfall Erosion Losses-A Guide to Conservation Planning. Agriculture Handbook No. 537, Department of Agriculture, Science and Education Administration.

Yin, S., Nearing, M. A., Borrelli, P., \& Xue, X. (2017). Rainfall Erosivity: An Overview of Methodologies and Applications. Vadose Zone Journal, 16, Article ID: vzj2017.06.0131. https://doi.org/10.2136/vzj2017.06.0131 